\title{
New Sulphur Oxidizing Bacteria Isolated from Bioleaching Pulp of Zinc and Copper Concentrates
}

\author{
N.S. Vardanyan*, A.K. Vardanyan \\ “Armbiotechnology" SPC of NAS of Armenia, Yerevan, 0056, Gyurjyan 14 \\ *Corresponding Author: avivardan@gmail.com
}

Copyright $@ 2014$ Horizon Research Publishing All rights reserved.

\begin{abstract}
Sulphur-oxidizing bacteria strain SO-1 and strain SO-2 have been isolated respectively from leaching pulp of zinc and copper concentrates. The cells of isolated bacteria are rods with the size of 0.3-0.5 x 0.7-2.0 mkm. They are capable of oxidizing elemental sulphur and tetrathionate with optimal growth temperature of $35^{\circ} \mathrm{C}$ and $\mathrm{pH}$ 2.7-3.0. The strains are considered to be facultative chemolithoautotrophic. Analysis of $16 \mathrm{~S}$ rRNA gene sequences has shown that the isolated strain SO-1 forms a single cluster with corresponding sequences of a type strain of Acidithiobacillus thiooxidans ATCC 19377 having $97.5 \%$ similarity with them. Strain SO-2 of sulfur-oxidizing bacteria isolated from leaching pulp of copper concentrate shows a high level of similarity with corresponding sequences of the type strain of Acidithiobacillus albertensis DSM-14366. We come to the conclusion that the strain SO-1 participating in the oxidation of zinc concentrate can represent a new species of the genus Acidithiobacillus distinct from A.thiooxidans and the strain SO-2 is a new strain of A.albertens.
\end{abstract}

Keywords Sulphur Oxidizing Bacteria - 16 S Rrna Gene Sequences - Acidithiobacillus Albertensis Bioleaching of Zinc and Copper Concentrates

\section{Introduction}

For long time it has been considered that only an extremely acidophilic $A$. thiooxidans (=Thiobacillus thiooxidans) is responsible for oxidation of elemental sulphur in nature and various bioleaching systems [14]. At present, a number of other obligate autotrophic acidophilic bacteria have been isolated which are able to oxidize elemental sulphur [3, 13, 16]. Among them, only Thiobacillus albertensis [16] and Acidithiobacillus caldus [12] are described as distinct species different from $A$. thiooxidans. Thiobacillus concretivorus, Thiobacillus kabobis, Thiobacillus capsulatus due to absence of significant differences from A.thiooxidans, in the latest publication of Bergey's Manual of Determinative
Bacteriology were recognized as synonyms of $A$.thiooxidans [1]. Later, on the base of analysis of $16 \mathrm{~S}$ rRNA nucleotide sequences Thiobacillus albertensis was included in the newly constructed genus Acidithiobacillus. Among these bacteria, special interest of scientists attracts $A$.caldus which is able to oxidize the elemental sulphur at elevated temperatures. According to some researchers A.caldus is the main sulphur-oxidizing bacterium in the reactors of biooxidation of gold concentrates which operates at $40^{\circ} \mathrm{C}$ $[9,11]$. According to the authors, the role of A.caldus in community of chemolithotrophic bacteria is the biooxidation of arsenopyrite to remove the inhibition layer of sulphur formed on the mineral surface or to provide mixotrophic and heterotrophic growth of other sulphur and iron oxidizing bacteria [8].

As for A.albertensis, there is no data about the potential role of this bacterium in biotechnology of metals.

Our previous studies on bioleaching of copper and zinc concentrates by the natural consortia of chemolithotrophic bacteria have shown that during bacterial oxidation of mentioned concentrates under the influence of appropriate physico-chemical and mineralogical factors a special microbial community is formed consisting of predominantly sulphur oxidizing bacteria, as well as iron oxidizing leptospirilli which are the most adapted to the leaching conditions of the mentioned concentrates.

Pure cultures of two strains of sulphur oxidizing mesophilic bacteria have been isolated from bioleaching pulp of the mentioned concentrates $[18,20]$.

The aim of this research was to study the main physiological properties of sulphur oxidizing bacteria isolated by us from the leaching pulp of zinc and copper concentrates and their identification on the base of $16 \mathrm{~S}$ rRNA nucleotide sequence analysis.

\section{Materials and Methods}

\section{Isolation of Sulphur Oxidizing Bacteria}

Strains SO-1 and SO-2 of sulfur oxidizing bacteria studied in this paper were isolated from leaching pulp of copper and zinc concentrates using $9 \mathrm{~K}$ medium with elemental sulfur as 
energy source. The sulphur was sterilized separately by flowing steam and added to the medium immediately before inoculation, $\mathrm{pH}$ was adjusted to $3.0-3.5$ with $10 \mathrm{~N} \mathrm{H}_{2} \mathrm{SO}_{4}$. Incubation was carried out stationary at $37^{\circ} \mathrm{C}$. Pure cultures were obtained by plating enrichment cultures of sulphur oxidizing bacteria on solid medium containing $0.6 \%$ agarose (Sigma), and $5 \mathrm{mM}$ sodium tetrathionate $\left(\mathrm{Na}_{2} \mathrm{~S}_{4} \mathrm{O}_{6} \cdot 2 \mathrm{H}_{2} \mathrm{O}\right)$ as the source of energy. The purity of isolates was checked on the same medium containing 0.05 to $0.1 \%$ yeast extract or glucose as the only source of energy.

Gram staining was performed by the method of Huker [10]. The bacterial ability of spore formation was checked by seeding heat treated cells on the nutrient medium mentioned above, as well as using special staining methods for spores [10].

The growth of isolated strains was assessed by increase of optical density and decrease of $\mathrm{pH}$ of the medium, as well as $\mathrm{SO}_{4}{ }^{2-}$ formation resulted from the oxidation of elemental sulphur. Sulfate ions were determined spectrophotometrically by the method of Dodgson [7].

Morphology of isolated bacterial cells was studied by the microscope Leica DM500 trinocular $(\times 1000)$, Software Digital Camera EC3 Leica Microsystem $(\times 10)$.

Experiments on bioleaching of zinc and copper concentrates were performed in the periodic regime. Samples of the concentrate were disintegrated to particles $0.045 \mathrm{~mm}$ in size. Loads of disintegrated samples were placed into Ehrlenmeyer's flasks $(250 \mathrm{ml}$ volume $)$, moistened with water, and sterilized at $0.5 \mathrm{~atm}$ for $30 \mathrm{~min}$. Then, the flasks were filled with $50 \mathrm{ml}$ of $9 \mathrm{~K}$ medium (acidated to $\mathrm{pH} 2.0$ ) without iron, and bacterial association $(5 \%)$ was introduced. Intensity of concentrate desalinization was assessed on the amount of desalinized copper, zinc, and iron as well as on reduction of $\mathrm{pH}$ of the medium and on titer increase for sulphur and iron oxidizing bacteria.

The amount of leached copper, zinc and iron was investigated using atomic absorption spectrophotometer AAS IN (Carl Zeiss, Germany).

\section{DNA Extraction}

Isolation of DNA from bacterial biomass was performed according to the method of Birnboim and Dolly [2]. The concentration of DNA samples obtained using this method was $30-50 \mu \mathrm{g} / \mathrm{ml}$.

\section{S rRNA Gene PCR}

The polymerase chain reaction (PCR), and further sequencing of PCR fragments 16S rRNA genes were performed using universal primer system [13]. Amplification mixture of $50 \mu \mathrm{l}$ contained: 1xDNA polymerase buffer BioTaq (17 mM ( $\left.\mathrm{NH}_{4}\right)_{2} \mathrm{SO}_{4}, 67 \mathrm{mM}$ Tris- $\mathrm{HCl}, \mathrm{pH} 8.8,2 \mathrm{mM}$ $\left.\mathrm{MgCl}_{2}\right), 12.5 \mathrm{nM}$ of each dNTP, $50 \mathrm{ng}$ of DNA, 5 pmol of the corresponding and 3 units of DNA polymerase BioTaq (Dialat LTD, Russia).

The temperature-time profile of PCR was as follows: first cycle $-94^{\circ} \mathrm{C}$ x $9 \mathrm{~min}, 55^{\circ} \mathrm{C}$ x $1 \mathrm{~min}, 72^{\circ} \mathrm{C}$ x $2 \mathrm{~min}, 30$ cycles of the following $-94^{\circ} \mathrm{C}$ x $1 \mathrm{~min}, 55^{\circ} \mathrm{C}$ x $1 \mathrm{~min}, 72^{\circ} \mathrm{C}$ x $2 \mathrm{~min}$, final cycle $-72^{\circ} \mathrm{C}$ x $7 \mathrm{~min}$

PCR products were purified using Wizard PCR Preps Kit (Promega, USA) according to the manufacturer's recommendations.

\section{Sequencing of PCR Products}

Sequencing of the PCR fragments of the genes encoding 16S rRNA was performed by the method of Sanger et al. [19] using the reagents Kit Big Dye terminator v.3.1 (Applied Biosystems, Inc., USA) on an automatic sequencer ABI PRIZM 3730 (Applied Biosystems, Inc., USA) according to the manufacturer's instructions.

\section{Analysis of $16 S$ rRNA Sequences}

Preliminary analyses of identity of nucleotide sequences of 16S rRNA genes of studied strains were performed using BLAST software package (http:www.ncbi.nlm.nih.gov/blast) [17].

\section{Results}

\section{Bioleaching of Copper and Zinc Concentrates}

Copper and zinc concentrates of Zangezur copper-molybdenium factory (Armenia) have been undergone bioleaching by community of chemolithotrophic iron oxidizing bacteria isolated from Akhtala polymetalic ores (Armenia), as well as pure culture of moderate thermophilic bacteria Sulfobaccillus thermosulfidooxidans.

Comparative activities of community of chemolithotrophi c iron oxidizing bacteria and pure culture of $S$. thermosulfidooxidans strain 86 for bioleaching of copper concentrate have been studied. It has been established high efficiency of bacterial consortium isolated from Akhtala polymetallic ore in bioleaching of copper concentrate in comparison with $S$. thermosulfidooxidans (Figure 1).

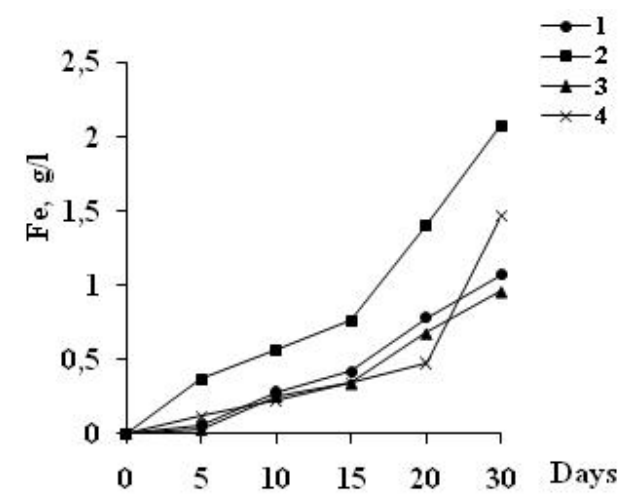

Figure 1. Bioleaching of copper concentrate by S.thermosulfidooxidans strain $86(1,3)$ and community of iron oxidizing bacteria $(2,4)$

The investigations have shown that application of community of iron oxidizing bacteria for bioleaching of zinc concentrate allows enhancing zinc extraction 3.3-fold, copper 4-5-fold, and iron 2-fold higher compared with the noninoculated control (Figure 2). 


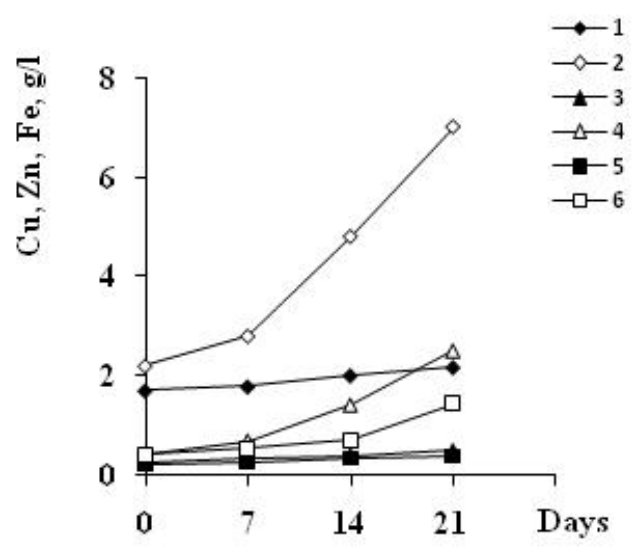

Figure 2. Kinetics of leaching of zinc $(1,2)$, copper $(3,4)$ and iron $(5,6)$ during chemical $(1,3,5)$ and bacterial oxidation of zinc concentrate $(2,4,6)$

\section{Microbiological Analysis of the Pulp}

Microbiological studies showed that by the end of the experiment sulphur oxidizing bacteria were dominant in the leaching pulp of zinc concentrate. The amount of sulphur oxidizing bacteria reached $10^{8}-10^{9}$ cells $/ \mathrm{ml}$, while the amount of iron oxidizing bacteria, presented predominantly by leptospirilli, did not exceed $10^{4}-10^{5}$ cells $/ \mathrm{ml}$. Probably, conditions in the pulp are changing during bioleaching of zinc concentrate and are becoming more favorable for the growth of sulphur oxidizing bacteria. As it was mentioned above, this, firstly, is connected with the accumulation of elemental sulphur in the medium as a product of chemical and bacterial oxidation of zinc and copper $[18,20]$.

\section{Cultural and Morpho-Physiological Properties}

Two strains of Gram negative sulphur oxidizing bacteria have been isolated from natural association of leaching pulp of zinc and copper concentrates: strain SO-1 and strain SO-2 respectively. The main physiological properties of strain SO-2 isolated from the copper concentrate leaching pulp are presented in the previously published work [18].

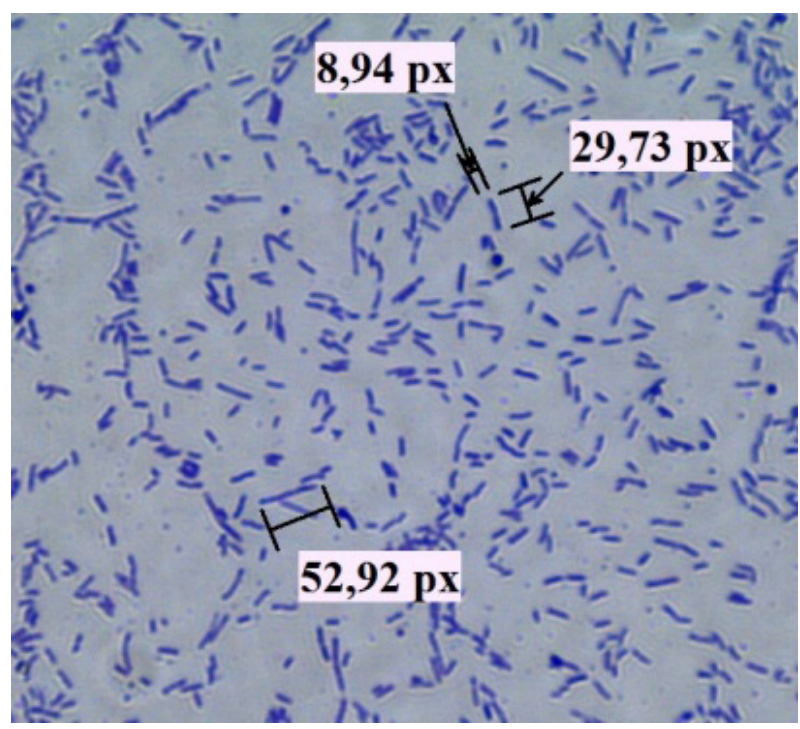

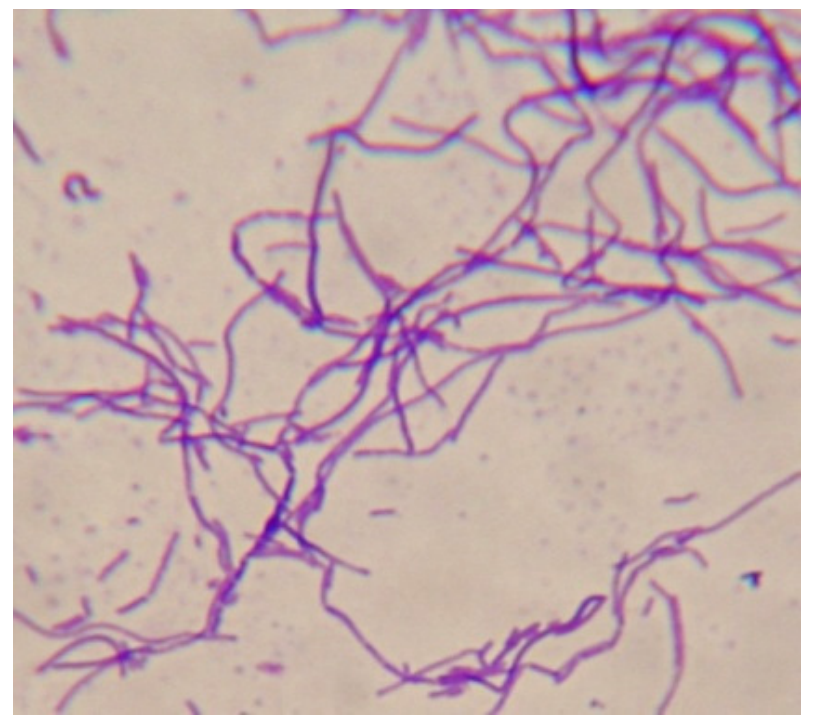

B

Figure 3. Microphotography of the cells of sulphur oxidizing bacteria strain SO-1 (A) and SO-2 (B) stained by Cristalline Violet (1 pixcel (px) = $263,6 \mathrm{mkm})$

Studies have shown that during the growth on solid medium with tetrathionate strain SO-1 forms regular white colonies coated with a thick layer of mucus. The cells represent motile rods with the size of 0.3-0.5 x 0.7-2.0 mkm (Figure 3), whereas the cells of strain SO-2 with the growth turn into long filaments, sometimes intertwined [18].

As the source of energy isolated strains can use elemental sulphur $\left(\mathrm{S}^{\circ}\right)$ and tetrathionate $\left(\mathrm{NaS}_{4} \mathrm{O}_{6} \cdot 2 \mathrm{H}_{2} \mathrm{O}\right)$. On the medium with elemental sulphur intensive growth of bacteria, increase in the optical density of the mediun and its acidification as a result of active formation of sulfuric acid have been observed after 5-7 days.

The growth of isolated bacteria in a medium with elemental sulphur occurs in the range of temperature $25-40^{\circ} \mathrm{C}$. The optimum temperature for the growth of strains is $35^{\circ} \mathrm{C}$ (Figure 4 ).

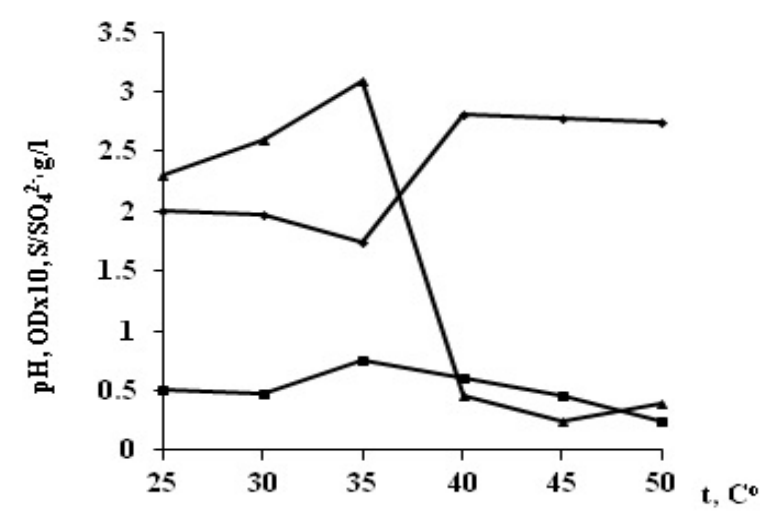

Figure 4. Effect of temperature on the growth of strain SO-1 and oxidation of elemental sulphur (duration - 9 days) $\diamond$-pH, - -optical density (ODx10), $\Delta-\mathrm{S}^{-} \mathrm{SO}_{4}{ }^{2-}$

Bacterial growth was observed in the range of $\mathrm{pH}$ 
of 2.0-4.0. The maximum growth rate and oxidation of elemental sulphur appeared at pH 2.7-3.0 (Figure 5).

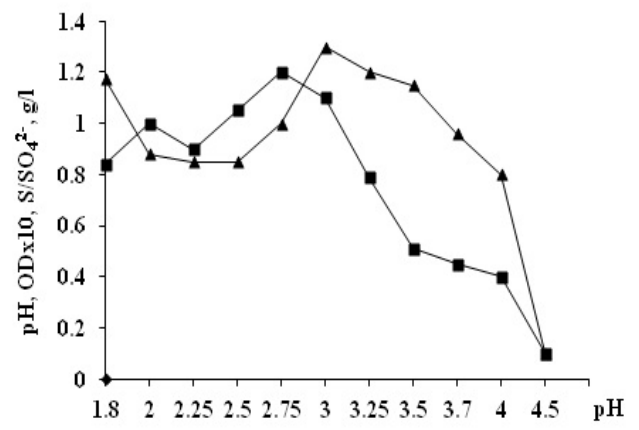

Figure 5. The growth of bacteria strain SO-1 and oxidation of elemental sulphur depending on $\mathrm{pH}$ (duration 8 days) $\mathrm{S} / \mathrm{SO}_{4}{ }^{2-}, \mathrm{g} / \mathrm{l}$

Studies have shown that yeast extract in concentration of $0.005-0.01 \%$ promotes the growth of bacteria and oxidation of elemental sulphur. Further increase of the concentration of yeast extract inhibits the growth of bacteria and oxidation processes (Figure 6).

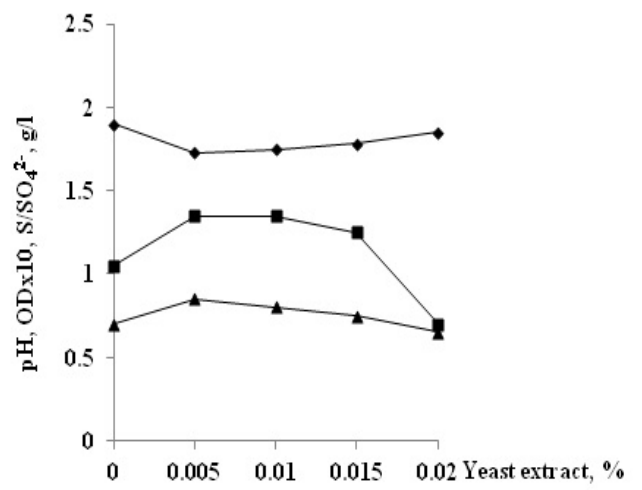

Figure 6. Effect of yeast extract on the growth strain SO-1 and oxidation of elemental sulphur (duration-10 days), $\diamond$-PH, -optical density (OD x 10), $\boldsymbol{\Delta}-\mathrm{S} / \mathrm{SO}_{4}{ }^{2-}, \mathrm{g} / 1$
The results obtained indicate that the isolated strain SO-1 is chemolithoautotrophic which receives energy for its activity in the process of oxidation of inorganic substances such as reduced sulfur compounds, thus fixing the carbon dioxide from the atmosphere or using organic carbon sources.

\section{Analysis of 16S rRNA Gene Sequences}

The identification of isolated strains was carried out by the analysis of $16 \mathrm{~S}$ rRNA gene nucleotide sequences. The sequenced fragments of the gene encoding 16S rRNA with the length of 1480 and 1478 nucleotides, respectively, corresponding to the positions from 20 to 1505 , and 19 to 1502 of E.coli were analyzed.

Preliminary screening of the GenBank database was performed using BLAST (http:www.ncbi.nlm.nih.gov/blast) [9]. On the base of comparative phylogenetic analysis it was revealed that the closest nucleotide sequences of $16 \mathrm{~S}$ rRNA of the strains SO-1 and SO-2 were the corresponding sequences of two species of the genus Acidithiobacillus: Acidithiobacillus albertensis strain DSM 14366 (NR_028982) (strain type species A.albertensis) and Acidithiobacillus thiooxidans ATCC19377 (Y11596) (type strain species A.thiooxidans).

For a more exact definition of an accessory of the strains the phylogenetic tree was constructed (algorithm-neighbor-j oining).

According to obtained dendrogram the sequences of $16 \mathrm{~S}$ rRNA of the strain SO-1 with a low level of reliability $(56 \%)$ forms a single cluster with the corresponding nucleotide sequencec of the type strain species of $A$. thiooxidans ATCC19377 (sequence similarity level - 97.5\%), and the nucleotide sequences of $16 \mathrm{~S}$ rRNA of the strain SO-2 with low reliability (less than 50\%) forms a cluster with the corresponding sequences of A.albertensis strain DSM 14366 (similarity level sequences - 99.9\%) (Table 1, Figure 7).

Table 1. Levels of similarity of $16 \mathrm{~S}$ rRNA nucleotide sequences of the strains SO-1, SO-2, and the phylogenetically closest species

\begin{tabular}{|c|c|c|c|c|}
\hline Bacterial strains & Strain SO-1 & Strain SO-2 & $\begin{array}{c}\text { Acidithiobacillus thiooxidans } \\
\text { ATCC 19377 T (AY552087) }\end{array}$ & $\begin{array}{c}\text { Acidithiobacillus albertensis } \\
\text { DSM 14366 T NR_(028982) }\end{array}$ \\
\hline Strain SO-1 & ID & 0.997 & 0.975 & 0.997 \\
\hline Strain SO-2 & 0.997 & ID & 0.974 & 0.999 \\
\hline $\begin{array}{c}\text { Acidithiobacillus thiooxidans } \\
\text { ATCC 19377 T (AY552087) }\end{array}$ & 0.975 & 0.974 & ID & 0.973 \\
\hline $\begin{array}{l}\text { Acidithiobacillus albertensis } \\
\text { DSM 14366 T NR_(028982) }\end{array}$ & 0.997 & 0.999 & 0.973 & ID \\
\hline
\end{tabular}




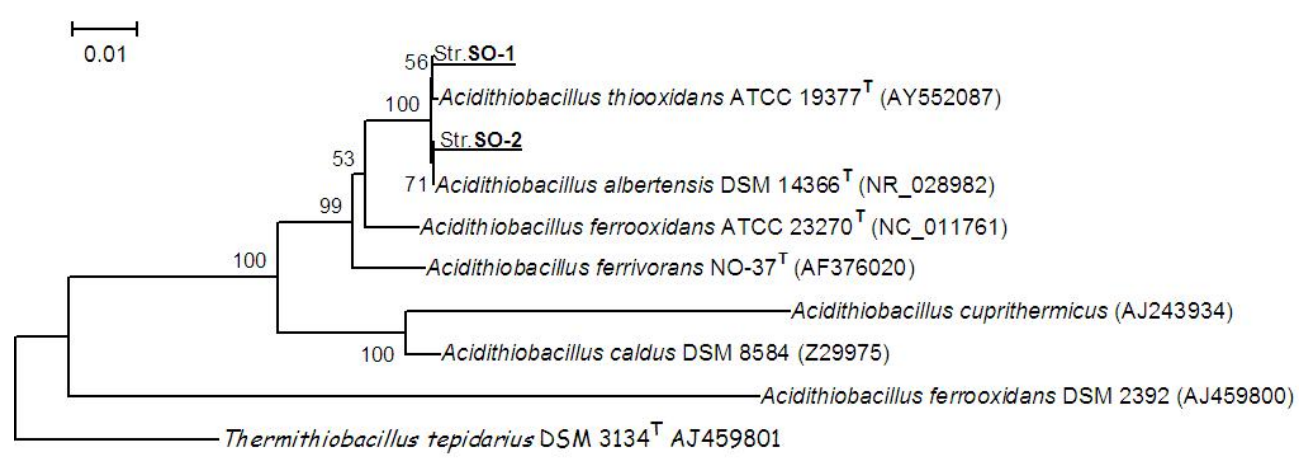

Figure 7. The phylogenetic position of the isolated strains within the genus Acidithiobacillus. The algorithm for constructing the dendrogram 'neighbor-joining' on the basis of comparison of 500 alternative trees. The scale at the left top designates evolutionary distances. The reliability of embranchment is expressed by percentage. Only the values higher of $50 \%$ were indicated. As an outgroup the nucleotide sequences of the 16S rRNA gene of the type species of Thermithiobacillus tepidarius DSM 3134 were used

\section{Conclusion}

Taking into account the fact that the level of similarity of nucleotide sequences of type strains of $A$. thiooxidans and $A$. albertensis is $97.3 \%$, it can be concluded that strain SO-1 may be a new species of the genus Acidithiobacillus, different from $A$. thiooxidans, while the strain SO-2 represents a new strain of $A$. albertensis.

\section{REFERENCES}

[1] Bergey's Manual of Systematic Bacteriology /Eds. Staley J.T., Bryant M.P., Pfenning N., Holt J.G., 3, 1842- 1853, 1989.

[2] Birnboim H. C., Doly J. A rapid alkaline extraction procedure for screening recombinant plasmid DNA // Nucleic Acids Res., 7, 6, 1513-1523, 1979.

[3] Bryant R.D., McGroarty K.M., Costerton J.W. Isolation and characterization of a new acidophilic Thiobacillus species (T.albertis). Canad. J. Microbiol, Vol.23, 9, 1159-1170,1983

[4] Buligina E.S., Kuznetsov B.B., Marusina A.I., Kravchenko I.K., Bikova S.A., Kolganova T.V., Galchenko V.F. Study of nucleotide sequences of genes nifH of methanotropihc bacterioa. Microbiology, Vol.71, 4, 500-508, 2002.

[5] Camacho C., Coulouris G., Avagyan V., Ma N., Papadopoulos J., Bealer K., Madden T. L., BLAST: architecture and applications.BMC Bioinformatics, Dec. 15; Vol.10, 421, 2009.

[6] Coram, N.J. and Rawlings, D.E. Molecular relationship between two groups of Leptospirillum and the finding that Leptospirillum ferriphilum sp. nov. dominates South African commercial biooxidation tanks which operate at $40 \mathrm{oC}$. Appl. Environ. Microbiol. Vol.68, 838-845, 2002.

[7] Dodgson R.S. Determination of Inorganic Sulphate in Studies on the Enzymic and non-enzymic Hydrolysis of Carbohydrate and OtherSulphate Esters. Biochem.J. Vol.78, 312-319, 1961.

[8] Dopson M., Lindstrom E.B. Potential role of Thiobacillus caldus in Arsenopyrite Leaching. Appl. Environ. Microbiol. Vol.65, 1, 36-40, 1999.
[9] Dopson M., Lindstrom E.B. Analysis of Community Composition during Moderately Thermophilic Bioleaching of Pyrite, Arsenical pyrite, and Chalcopyrite. Microbial Ecology, Vol.48, 1, 19-28, 2004.

[10] Gerkhard F. et al., Methods of general Microbiology, Part 1, Mir, Moscow, 1983.

[11] Goebel B.M., Stackebrandt E. Cultural and phylogenetic analysis of mixed microbial populations found in natural and commercial bioleaching environments. Appl. Environ. Microbiol. Vol.60, 1614-1621, 1994.

[12] Hallberg, K.B. and Lindström, E.B. Characterization of Thiobacillus caldus sp. nov., a moderately thermophilic acidophile. Microbiology Vol.140, 3451-3456, 1994.

[13] Hallberg, K.B. and Johnson, D.B. Biodiversity of acidophilic prokaryotes. Adv. Appl. Microbiol. Vol.49, 37-84, 2001.

[14] Karavaiko G.I., Kuznetsov S.I., Golomzik A.I., The role of microorganisms in bioleaching of metals from ores. M., Nauka, p.248, 1972.

[15] Kelly D.P., Wood A.P. Reclassification of some species of Thiobacillus to the newly designated genera Acidithiobacillus gen. nov., Halothiobacillus gen. nov. and Thermithiobacillus gen. Int. J. Syst. Evol. Microbiol. Vol.50, 511-516, 2000.

[16] Laishly E.J., Rae K., Dillman A.M., Bryant R.D., Characterization of a new acidophilic Thiobacillus isolate (Thiobacillus capsulatus). Canad. J. Microbiol. Vol.34, 960-966, 1988

[17] Lane D. J. 16S/23S sequencing // In: Nucleic acid techniques in bacterial systematics / Stackebrandt E. a. Goodfellow M. (Eds.). - Chichester: John Wiley \& Sons, Ltd., 115-175, 1991.

[18] Naghdalyan S.Z., Kocharyan Y.M., Vardanyan N.S. Peculiarities of the association of chemolithotrophic bacteria during leaching of copper concentrate. Biolog. J. Armenia, Vol.61, 1, 18-23, 2009.

[19] Sanger F., Nicklen S., Coulson A.R. DNA sequencing with chain-terminating inhibitors. Proc. Natl. Acad. Sci. USA, Vol. 84, 5463-5467, 1977.

[20] Vardanyan N.S., Vardanyan A.K., Selective Extraction of Metals from Zinc Concentrate by Association of Chemolithotrophic Bacteria. Appl. Biochem. Microbiology, Vol. 47, 5, 566-571, 2011. 